\title{
Echinoid distribution and sequence stratigraphy in the Cenomanian (Upper Cretaceous) of southern England
}

\begin{abstract}
Andrew B. Smith ${ }^{1}$, Neale E. A. Monks ${ }^{1,2}$ \& Andrew S. Gale ${ }^{3}$
SMITH, A. B., MONKS, N. E. A. \& GALE, A. S. 2006. Echinoid distribution and sequence stratigraphy in the Cenomanian (Upper Cretaceous) of southern England. Proceedings of the Geologists' Association, 117, 207-217. Almost 3500 individual occurrences of echinoid have been recorded and correlated against a sequence stratigraphic framework for the entire Cenomanian and basal Turonian from three regions of southern England, representing onshore, mid-shelf and deeper-shelf habitats. There are marked differences in the composition and diversity of faunas both across the shelf at a single time interval and through time at the same locality, driven primarily by factors such as sedimentary facies, which are controlled by changing sea-levels. The ranges of individual taxa expand and contract across the shelf as sea-levels change. In mid-shelf environments more onshore taxa appear only near sequence bases, at times of lowest sea-level, while those from more outer shelf settings are found during highstand intervals, and this creates a cyclical pattern of diversity. By comparison with modern faunas, the Middle and Upper Cenomanian of the Sussex coast is likely to have been deposited in water depths of between $100 \mathrm{~m}$ and $150 \mathrm{~m}$ and the amplitude of sea-level change appears to increase through the Cenomanian.
\end{abstract}

Key words: sea-level, diversity, diachroneity, faunal assemblages

${ }^{1}$ Department of Palaeontology, The Natural History Museum, Cromwell Road,

London SW7 5BD, UK (e-mail: a.smith@nhm.ac.uk)

${ }^{2}$ Present address University of Nebraska State Museum, Morrill Hall, Lincoln, Nebraska, 68588-0338, USA (e-mail: nmonks@mac.com)

${ }^{3}$ School of Earth and Environmental Sciences, University of Greenwich, Medway Campus,

Chatham, Kent ME4 4AW,UK (e-mail: a.s.gale@greenwich.ac.uk)

\section{INTRODUCTION}

Echinoids have been an important constituent of the modern marine macrobenthic community ever since the Late Triassic, and today are found across the full spectrum of marine habitats, from the intertidal zone down to depths of more than $5000 \mathrm{~m}$. Many factors control the distribution and preservation potential of individual taxa, the most important being nutrient availability, substrate type and turbulence (e.g. Nebelsick, 1995, 1996). All three are directly or indirectly correlated with water depth.

Life in rocky shore habitats requires special adaptations if epifaunal species are not to get torn off and crushed by powerful wave surge. This includes the development of large numbers of strong oral tube feet, the organs that are used for grip, stout spines for wedging into crevices and, in extreme cases, anen-

A version of this paper was presented orally at a joint meeting of the Geological Society of London, the Geologists' Association and the Palaeontological Association: The life and work of Jake Hancock (1928-2004) held at the Geological Society, Burlington House, London, 14 October 2004. The meeting was convened by Professor John C.W. Cope, who has also been Guest Editor for the manuscripts arising from the meeting, now published in the Proceedings. casement of tessellated aboral spines (as in the Upper Jurassic Acrocidaris (Baumeister \& Leinfelder, 1998) and the modern Colobocentrotus). Life in littoral sediments is equally precarious because of the dangers of being washed out and crushed by wave surge and in these environments deep burial is a common strategy developed by infaunal irregular echinoids.

Below the littoral zone to depths of approximately $30-50 \mathrm{~m}$ specialist algal grazers and herbivores are predominant amongst regular echinoids, and bulk sediment swallowers predominate amongst irregular echinoids. The latter ingest sediment more or less wholesale in order to exploit the small quantities of organic particles that it contains (Lawrence, 1987). However, as water depth increases, nutrient supply to the sea floor becomes significantly curtailed and the free organic material available in the sediment diminishes, making bulk sediment swallowing unfeasible. With increasing depth and reducing light penetration, the stands of macroalgae also disappear and algal grazers are confined to areas where there is a supply of drift macroalgae. Consequently, in mid to outer shelf settings the echinoid fauna changes to one dominated by regular carnivore species and irregular phytodetritus browsers that mine organics at the sediment-water 





interface and rely on the rain of organic material from surface waters. Within storm wave base there is sufficient lateral transportation of organic material from shallow water to maintain a diverse mixed echinoid fauna and, indeed, highest taxic diversity in Sagami Bay is found at c. 100-120 m water depth (Smith et al., 2001). Below this, however, diversity rapidly drops and bulk sediment swallowers and algal grazers are lost.

These clear changes in the population structure of echinoids in the present day are also recognizable in the geological past (e.g. Neraudeau \& Villier, 1996; Smith et al., 2001). This paper documents the stratigraphic distribution of echinoids across southern England during the Cenomanian, a time when sea-level was rapidly changing.

The aims of the article are two-fold: first to establish the precise ranges of echinoids in each section (summarized at genus level) collected by reference to stratigraphic horizons and tied into biostratigraphic and sequence stratigraphic schemes. Secondly, to explore how changing community structure may be related to sequence stratigraphy.

\section{METHODS AND MATERIALS}

\section{Echinoid trophic groupings}

A general description of the mode of life of Cenomanian echinoids can be found in Smith et al. (1988) and Neraudeau \& Moreau (1989). Echinoids from the Cenomanian of the UK fall into a number of broad categories.

\section{(i) Cidaroids (Fig. 1.1)}

Cidaroids are generalist carnivores, feeding on sessile organisms especially sponges (De Ridder \& Lawrence, 1982; Jacob et al., 2003). Cenomanian cidaroids fall into two easily distinguishable groups based on their spine morphology: those with long cylindrical spines, equal or greater than their test diameter in length (Stereocidaris, Phalacrocidaris, Prionocidaris, Hirudocidaris) and those with stout club-like spines (Tylocidaris). Both are widely distributed in all three study regions.

\section{(ii) Saleniids (Fig. 1.2)}

Today saleniids are restricted to the deep-sea environment and are presumably generalist carnivores, being much like cidaroids in habits and appearance. Cenomanian saleniids (Salenia, Goniophorus and Hypsosalenia), like cidaroids, occur in small numbers in inshore, mid-shelf and deeper shelf settings.

\section{(iii) Goniopygids}

These have expanded phyllodes orally and indicate the presence of nearby rocky substrates within wave base. Goniopygids are very rare and have been recorded only from SW Devon in the lowest, most inshore, beds.

\section{(iv) Other stirodonts}

The genera Tiaromma, Allomma, Glyphopneustes, Echinocyphus (Fig. 1.3), Glyptocyphus and Cottaldia (Fig. 1.4) are all forms with a sunken peristome and no phyllodes. Similar forms today are typically neritic in distribution and feed on macroalgae. They are common only in the Devon sections, but are occasionally found in Sussex and Norfolk.

Tetragramma and Polydiadema are slightly different, having weak phyllodes a flush peristome and a strongly flattened form. They are likely to be algal grazers living on or around hard substrata in the neritic zone. Both are common in the lower parts of the succession in Devon.

\section{(v) Discoidids and conulids}

There are no modern equivalents to Discoides, Camerogalerus (Fig. 1.5) or Conulus and so their mode of life and diet can only be guessed at. They were possibly epifaunal opportunists living on unconsolidated sediments and feeding on detached algal debris and small benthic organisms on the sea floor.

\section{(v) Cassiduloids}

The cassiduloids Catopygus (Fig. 1.6), Ochetes and Penesticta were all probably bulk sediment swallowers living in shallow-water clastic habitats within fair weather wave base. Echinogalerus is more likely to have been an epipsammic grazer (i.e. feeding on the organic particles adhering to individual grains without ingesting the grains themselves) judging from its size. Like modern cassiduloids, both fed on the organic material coating sediment grains (De Ridder \& Lawrence, 1982; Lawrence, 1987).

\section{(vi) Holasterids and spatangoids}

Cenomanian holasteroids are represented by flatbased Holaster and the rounded-based Crassiholaster

Fig. 1. Typical elements of the echinoid fauna of the Cenomanian-early Turonian of southern England. 1a, b, Hirudocidaris uniformis (Sorignet), NHM E76261. M. dixoni Zone, Lower Cenomanian, Wilmington, Devon: a, apical; b, lateral; $\times 2.25$. 2a, b, Hyposalenia clathrata (Woodward), NHM E10296. Lower Cenomanian [?Cast bed], Dover, Kent: a, apical; b, lateral; $\times 2.7$. 3a, b, Echinocyphus rotatus Cotteau, SM B98. Grey Chalk, Dover, Kent: a, apical; b, oral; × 1.8. 4, Cottaldia benettiae (König) NHM E42304. M. dixoni Zone, Lower Cenomanian, Wilmington, Devon; apical, $\times 1.35$. 5a, b, Camerogalerus minimus (Desor), NHM E59654. I. labiatus Zone, Lower Turonian, Charring, Kent: a, lateral; b, oral; × 2.7. 6a, b, Catopygus columbarius (Lamarck), NHM E80657. M. dixoni Zone, Lower Cenomanian, Wilmington, Devon: a, apical; b, oral; $\times 2.0$. 7a, b, Crassiholaster subglobossus (Leske). Grey Chalk, A. rhotomagense Zone, Oxted, Surrey: a, apical; b, oral; $\times 0.9$. 8a, b, Hemiaster (Bolbaster) nasutulus Sorignet, NHM E80642. I. labiatus Zone, Lower Turonian, Wilmington, Devon: a, apical; b, oral; $\times 2.25$. 



Fig. 2. Ammonite biostratigraphy and sequence stratigraphic framework for Cenomanian-basal Turonian sections in SE Devon (Branscombe-Beer and Wilmington), S. Sussex (Southerham and Beachy Head) and Norfolk (Hunstanton). Ammonite zonation follows Wright et al. (1984); systems sequences tracts are numbered 1-6 following Robaszynski et al. (1998). Note that only HS deposits of Sequence 2 are present in the UK. Abbreviations: DLS, downlap surface; HC, Haven Cliff hardground; HP, Humble Point hardground; HS, highstand system tract; J-B VII, Jukes-Brown Bed VII; KH, Kings Hole hardground; LIB, Lower Inoceramid bed; NS, Nettleton Stone; PB, Paradoxides bed; SB, sequence boundary; SC, Small Cove hardground; SMW, shelf margin wedge; TS, transgressive surface; TSt, Totternhoe Stone; TST, transgressive systems tract; W, Weston Hardground. Note that phosphatized fossils originating from the C. guerangeri Zone (white circles) can occur as reworked elements in Bed C.

(Fig. 1.7), Cardiaster, Cardiotaxis and Labrotaxis. Holaster was probably surface dwelling, feeding on accumulations of organic debris at the sediment-water interface. The others were infaunal deposit feeders. Spatangoids are represented by species of Hemiaster (Fig. 1.8) and Micraster. Both are infaunal detritivores, the former being deep-sea in distribution today.

\section{Sequence stratigraphic framework}

The Cenomanian was a time interval when sea-level was rising rapidly (Carter \& Hart, 1977; Hancock, 1989; Hart et al., 1992). Gale (1995), Gale et al. (1999) and Robaszynski et al. (1998) have constructed a detailed sequence stratigraphic framework for this time interval, recognizing five cycles during the 




Fig. 3. Distribution of echinoid genera in the Cenomanian to early Turonian of the coastal section between Branscombe and Beer, SE Devon. Abbreviations as in Figure 2. Scale bar on left is in metres.

Cenomanian based on the distribution of onshore hiatuses and on subtle changes in sedimentology and trace fossils in offshore settings. Robaszynski et al. (1998) summarized the way in which system tracts were identified. Figure 2 summarizes the sequence stratigraphic cycles plotted against the standard biostratigraphical scheme based on ammonites (Wright et al., 1984; Gale, 1995).

In the more onshore environments deposits can be quite thick locally but are very incomplete, with large intervals of time missing. Deposits in the more distal parts of the shelf tend to be sediment-starved and may also have significant time gaps. Only in mid-shelf environments is a more or less continuous record of deposition recorded, and here the well-developed chalk-marl couplets provide an absolute time-scale. Chalk-marl couplets are Milankovitch-scale deposits representing approximately $20 \mathrm{ka}$ time intervals (see Gale, 1990, 1995, Gale et al., 1999 for a full description).

\section{Studied sections}

Echinoids were collected from three localities, representing onshore, mid-shelf and outer shelf environments.

- SE Devon - The succession in SE Devon represents a relatively inshore environment. Gaps are numerous, commonly represented by hardgrounds, and coarse clastic sediments dominate all but the latest Cenomanian. These features are indicative of shallow-water conditions within normal wave base. Smith et al. (1988) provided detailed distributions of echinoderms from the inland locality of Wilmington, Devon [Grid Reference SY 208 997], while collecting from the coast exposures along the south Devon coast from Beer to Branscombe [SY 213880 to $227878]$ is summarized here. The stratigraphy and lithology of these beds was described by W. E. Smith (1957, 1961) and Jarvis \& Woodroof (1984). Individual specimens were recorded with respect to height (in centimetres) above one of a number of characteristic and easily recognizable hardgrounds in the succession. In total, 513 specimens were collected from the coastal section to complement the 1700 individuals tied to stratigraphical horizons from the White Hart Pit, Wilmington (Smith et al., 1988).

- Sussex - For the mid-shelf succession, data from Southerham Quarry and Beachy Head, Sussex were combined. The Chalk Marl is extremely well exposed at Southerham Quarry [TQ 427 091], while the upper part of the Chalk Marl and all of the Grey Chalk are exposed along the sea cliffs to the immediate East of Beachy Head [TV 603967 to 585953]. Gale (1995) and Gale et al. $(2000,2005)$ provided details 


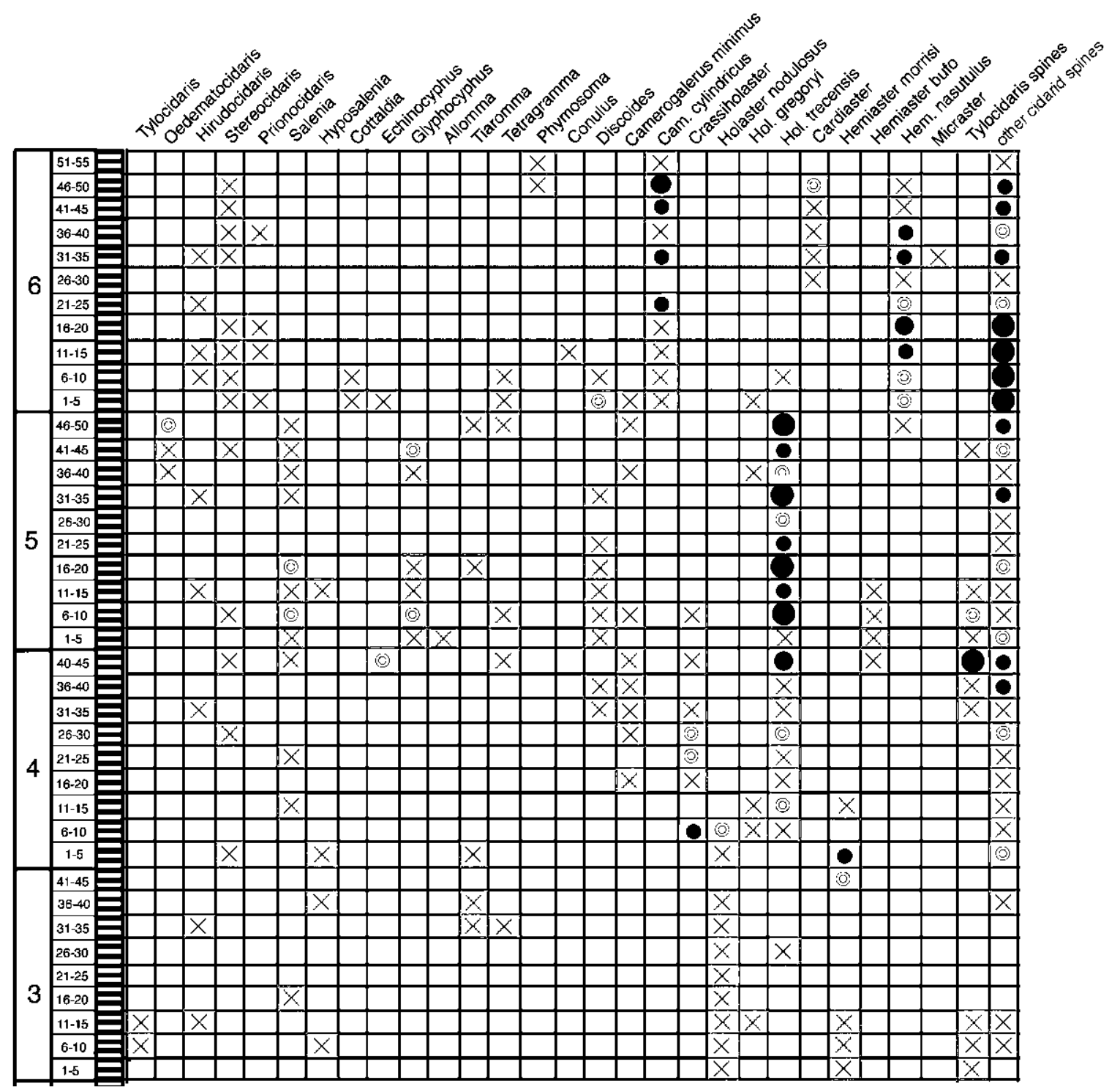

Fig. 4. Distribution of echinoid genera in the Cenomanian to early Turonian of S Sussex. Symbols as in Fig. 3; abbreviations as in Fig. 2. Scale bar on left is in chalk-marl couplets (c. 20000 -year time intervals) which are grouped into bundles of five and numbered within each sequence.

of the sections at Beachy Head. Throughout this succession chalk-marl couplets are very pronounced and individual specimens were collected by reference to specific chalk-marl couplets (individually numbered). A total of 689 identifiable echinoid tests and 437 cidaroid spines were collected.

- Norfolk - The cliff sections lying between the town of Hunstanton eastwards to St Edmund's Point [TF 672413 to 677424] yielded the core of the collections from here, but additional sampling of the higher Cenomanian succession was made at Hillington and Barrett Ringstead (see Gallois (1994) for details of all of these localities). Some 145 specimens were collected and their height recorded with respect to a series of easily recognizable marker horizons. The onset of pure chalk facies occurs earlier here than elsewhere and, although the succession is thin, deposition was in a more offshore environment.

The surface area of rock available at outcrop for fossil collection in these three areas does not differ greatly, except for the rather small representation of the higher beds available in the Devon sections. 


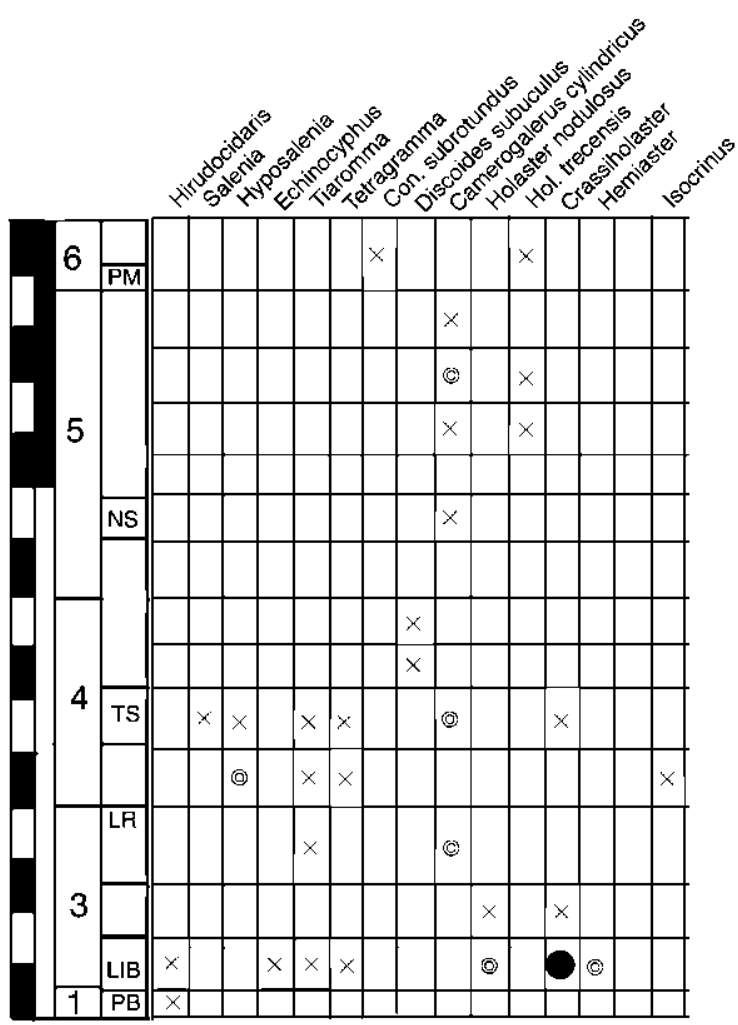

Fig. 5. Distribution of echinoid genera in the Cenomanian to early Turonian of N. Norfolk. Symbols as in Fig. 3; abbreviations as in Fig. 2 except for LR=Lower Orbirhynchia and $\mathrm{PM}=$ Plenus Marl; box shading as in Figure 3. Scale bar on left is in metres.

\section{RESULTS}

The stratigraphical ranges of the echinoid fauna from the three areas are summarized in Figures 3-5. Clear differences are seen between these areas, both in the composition of the faunas and in their relative diversities.

In the onshore settings of Devon (Fig. 3) a diverse community dominated by regular echinoids and cassiduloids is present in the early transgressive systems tracts (TST) sediments of Sequences 1 and 3, but this is replaced by a much lower diversity holasteroidcidaroid-spatangoid community in later cycles. The only other time that an epipsammic grazer or stirodont is found is close to the sequence boundary of Sequence 4.

In Sussex (Fig. 4) and Norfolk (Fig. 5), cassiduloids and epipsammic grazers are absent due to the absence of sandy facies, and the cyclicity in diversity is driven almost exclusively by the rise and fall in diversity of algal grazer species (irregulars being present throughout). A variety of regular echinoids appear at the sequence boundaries of Sequences 4, 5 and 6 in Sussex, but regulars are rarer in the silty transgressive sediments of Sequence 3.

In Norfolk regular algal grazer species are found at only two levels, immediately above the sequence boundaries of Sequences 3 and 4. In the upper beds just three species (Tylocidaris (spines only), Holaster trecensis and Camerogalerus cylindricus) co-occur in low numbers.

\section{DISCUSSION}

\section{Diversity and sequence stratigraphy}

Neraudeau et al. (1997), working at somewhat coarser resolution on the Cenomanian fauna of Charentes, France, concluded that echinoid diversity reached highest diversities at times of highest sea-levels. They were working in an inshore environment and their highest sea-levels corresponded to deep inner-shelf (neritic) settings. Comparing the three UK sections (Fig. 6) it is clear that greatest diversity of species is present in the transgressive system tracts (TST) of inshore settings and is lowest in the highstand system tracts (HS) of outer shelf settings. This pattern is most clearly seen in the mid-shelf setting at Eastbourne, Sussex where there are no significant breaks in sedimentation. Here a clear cyclicity in species diversity is apparent, with lows at the start of HST and peaks coinciding with system bases. This is apparent in the 100000 year plots (i.e. five chalk-marl couplets; Fig. 7). A weak cyclicity is also evident in the data of Neraudeau et al. (1997).

In inshore habitats diversity peaks during the TST of Sequence 3 and falls rapidly approaching the HS. It remains low in Sequence 4 (possibly in part an artefact of restricted outcrop area), but shows a small peak at the start of the TST of Sequence 6 before dropping once more to low levels.

In outer shelf habitats diversity is always low, but peaks twice - once in the TST of Sequence 3, where species diversity is at its greatest, and a second, smaller peak associated with the TST of Sequence 4. In contrast to Eastbourne and Devon, no increase in diversity is associated with the sequence boundary at the base of Sequence 6, suggesting that in this part of the shelf water remained relatively deep.

In comparison to both Norfolk and Devon, the faunal diversity of the Early Cenomanian in Sussex is anomalously low. This may be because of the high silt content of the beds that presumably indicates highly turbid waters. The fauna of spatangoids, holasteroids and cidaroids found in these beds is typical of a community living below the photic zone.

\section{Diachronous distributions and range expansions}

During a transgressive-regressive cycle, as water depth changed over the shelf, one might expect to find evidence for changes in the geographical range of 


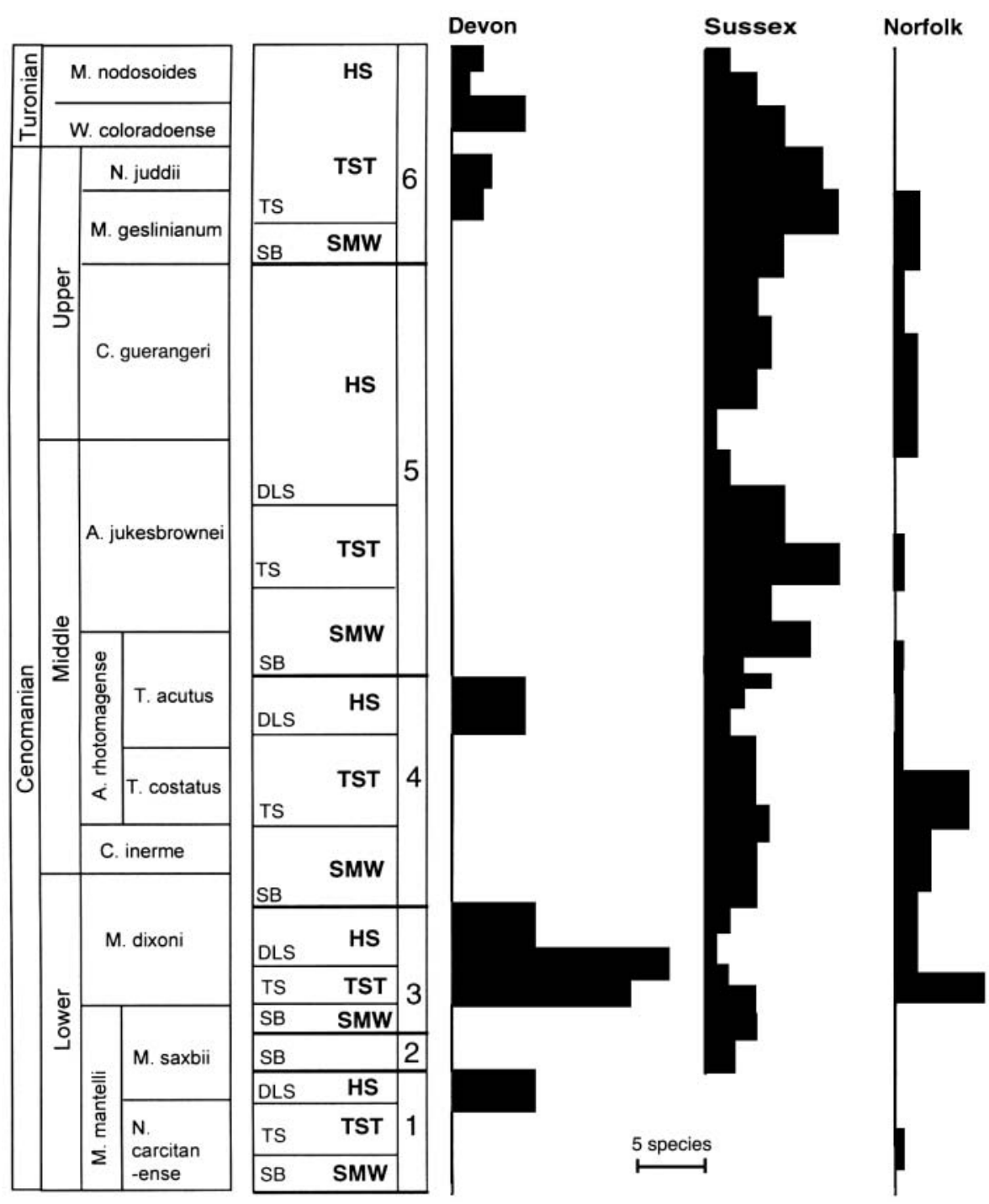

Fig. 6. Comparative diversity of echinoids in onshore, mid-shelf and deeper-shelf settings plotted against sequence stratigraphy. Abbreviations as in Figure 2.

species during different parts of the sequence stratigraphy (see Patzkowsky \& Holland, 1993, 1996; Brett, 1995; Neraudeau \& Villier, 1996). Deeper-water species should appear first in offshore settings and migrate into more onshore settings only later, once sea-levels have risen. Similarly, one might expect to see shallow-water taxa migrating into more outer shelf settings during times of lowest sea-level stand. Both patterns can be identified during the Cenomanian.

\section{Range expansion of deep-water taxa during transgressive phases}

There are two clear examples of deeper-water taxa that migrate over time into more onshore settings as water depth increased. The earliest record of the holectypoid Camerogalerus in the three regions is in HS of Sequence 3 in Norfolk, and it continues to occur in higher beds through to the top of Sequence 5. In Sussex the first Camerogalerus does not appear until the HS of Sequence 4, where it becomes moderately common. In Devon rare small individuals are found in the upper parts of the TST of unit 4 and as remanié specimens in overlying transgressive beds of Sequence 5.

A similar pattern is shown by the holasteroid Crassiholaster, which first appears at the base of the TST of Sequence 3 in Norfolk and reappears in TST of Sequence 4. In Sussex, Crassiholaster does not appear 


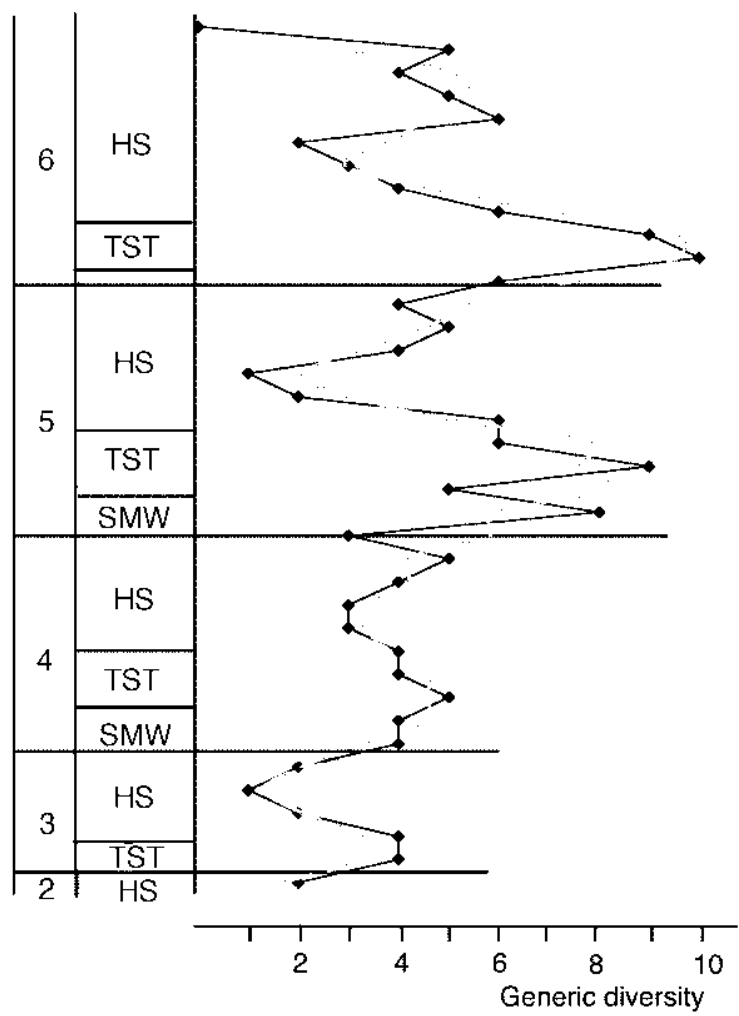

Fig. 7. Diversity of echinoids in southern Sussex grouped into bundles of five chalk-marl couplets (approximately 100000 year intervals) plotted against sequence stratigraphy. The grey dashed line indicates a three-point moving average. Abbreviations as in Figure 2.

until the top of the TST of Sequence 4 and, like Camerogalerus, is moderately common throughout the HS of that cycle. In Devon, Crassiholaster comes only in the HST of Sequence 3, and is also found in the HST of Sequence 4.

For both Camerogalerus and Crassiholaster, their earliest appearances are in the deeper-water sediments of Norfolk and they have only expanded their ranges across into Sussex and Devon during periods of high sea-level stand.

\section{Range expansion of shallow-water taxa during regressive phases}

A number of regular echinoids that appear commonly in the TST and HS beds of Sequences 1 and 3 in Devon appear only later in the late SMW or basal TST parts of sequences in Sussex. Cottaldia, for example, is moderately common in the TST part of Sequence 3 in Devon, after which it more or less disappears. However, it does occur rarely close to the system base of Sequence 6 in Sussex, when conditions there were at their shallowest. Echinocyphus and Tetragramma show a similar pattern, with the latter also appearing in the late SMW Sequence 4 and basal TST of Sequence 5 in Sussex and Norfolk, but only in the late SMW Sequence 5 and basal TST of Sequence 6 in Sussex. These represent shallow-water taxa that have expanded over the shelf during periods of low sea-level stand.

\section{Palaeobathymetric interpretation of cycles}

In Devon the presence of a diverse fauna of stirodont echinoids indicates proximity to macroalgal stands probably within $c .50 \mathrm{~m}$ water depth. Similarly, the presence of epipsammic grazers and bulk sedimentswallowing cassiduloids imply unconsolidated sediments within the same sort of depth range. These two groups predominate in the TST and HS parts of Sequences 1 and 3 in Devon but are absent from younger deposits, implying that water depths were greater than $50 \mathrm{~m}$ during the later TST and HS periods. However, phosphatized cassiduloids and stirodonts are known from remanié deposits representing Bed $\mathrm{C}$ elsewhere in Devon (data not presented) and suggest that shallow-water conditions may have returned briefly during the regression at the end of Sequence 5 .

By contrast, in Sussex, faunal diversity was low in the early sequences and algal grazers are extremely rare. This may be because the area was initially too deep to support a diverse community, or because the high silt content made the waters turbid, severely reducing light penetration. Higher in the section, when the silt content of the sediments was lower and the waters presumably clearer, there is a clear oscillation between more diverse faunas that include small numbers of algal grazers, and low diversity faunas dominated by surface-feeding holasteroids. The high diversity faunas coincide with the shallowest parts of each cycle, around the sequence boundaries, while the lowest diversities occur during the HS intervals. In present-day settings algal grazers more or less disappear at depths greater than about $100-120 \mathrm{~m}$ (Smith et al., 2001) to be replaced by spatangoidcidaroid communities. So the marked oscillation in diversity and the presence of a small number of algal grazers at the shallowest parts of the sequences, suggest water depths were in the range of $100-150 \mathrm{~m}$.

Interestingly the amplitude of the diversity cycles increases through the Cenomanian, suggesting that sea-level fluctuations were becoming more extreme over time.

In Norfolk, echinoid diversity was never great, but was at its maximum when sea-level was lowest during the earlier sequences. A low diversity community dominated by holasteroids, cidaroids and Camerogalerus was the only community present throughout most of the succession. This suggests that during the regression at the end of Sequence 5 water depth remained greater than $100-120 \mathrm{~m}$ in this region of the shelf. 
Holland (1995), in a pioneering paper, first established through computer modelling that sequence stratigraphic architecture would have a major controlling influence over taxonomic diversity and the distribution of first and last occurrences. Empirical work byPatzkowsky \& Holland $(1993,1996)$ on the distribution of Ordovician brachiopods lent support. The analysis here of shelf echinoid faunas during the Cenomanian, together with earlier studies of the Cenomanian-Turonian boundary (Gale et al., 2000, Smith et al., 2001), confirms the close connection that exists between sequence stratigraphic architecture and faunal diversity patterns.

\section{CONCLUSIONS}

Because the composition and preservational potential of echinoid communities is controlled by factors that are predominantly depth-related, a strong correlation exists between species diversity and the sequence stratigraphic cycles that make up the rock record. Diversity in onshore environments is high in the Cenomanian but restricted largely to transgressive and early high- stand intervals, as these are the only times when significant sedimentary deposits were preserved. Diversity decreases significantly below about $100-120 \mathrm{~m}$ water depth in modern settings, and is lowest in the deeper-water parts of the continental shelf during the Cenomanian.

Changing sea-level creates a cyclical diversity curve in mid-shelf environments of south Sussex in the Cenomanian primarily because of the expansion of the diverse fauna of algivores and other predominantly onshore taxa across the shelf during times of low sea-level stand (i.e. close to the sequence boundaries). Conversely, at times of high sea-level stand, a low diversity fauna typical of outer shelf settings expands into this region. The pattern of taxonomic appearances and disappearances is also highly predictable from the sequence stratigraphic architecture.

\section{ACKNOWLEDGEMENTS}

The authors are grateful to the two referees, Chris Paul and Jim Kennedy, for helpful suggestions that have improved this paper. Fieldwork was supported by a NERC research grant.

\section{REFERENCES}

Baumeister, J.G. \& Leinfelder, R.R. 1998. Constructional morphology and palaeoecological significance of three late Jurassic regular echinoids. Palaeontology, 41, 203-219.

Brett, C.E. 1995. Sequence stratigraphy, biostratigraphy, and taphonomy in shallow marine environments. Palaios, 10, 597-616.

Carter, D.J. \& Hart, M.B. 1977. Aspects of mid-Cretaceous stratigraphical micropalaeontology. Bulletin of the British Museum (Natural History) Geology Series, 29, 1-135.

De Ridder, C. \& Lawrence, J.M. 1982. Food and feeding mechanisms: Echinoidea. In (Jangoux, M. \& Lawrence, J.M.; eds) Echinoderm Nutrition. A. A. Balkema, Rotterdam, 57-115.

Gale, A.S. 1990. A Milankovitch scale for Cenomanian time. Terra Nova, 1, 177-197.

Gale, A.S. 1995. Cyclostratigraphy and correlation of the Cenomanian of western Europe. In (House, M.R. \& Gale, A.S.; eds) Orbital Forcing Timescales and Cyclostratigraphy. Geological Society, London, Special Publications, 85, 177-197.

Gale, A.S., Hancock, J.M. \& Kennedy, W.J. 1999. Biostratigraphical and sequence correlation of the Cenomanian successions in Mangyshlak (W. Kazakhstan) and Crimea (Ukraine) with those in southern England. Bulletin de l'Institut Royal des Sciences Naturelles de Belgique, Sciences de la Terre, 69-Supp. A, 67-86.

Gale, A.S., Smith, A.B., Monks, N.E.A., Young, J.A., Howard, A., Wray, D.S. \& Huggett, J.M. 2000. Marine biodiversity through the Late Cenomanian-Early Turonian: palaeoceanographic controls and sequence stratigraphic biases. Journal of the Geological Society, London, 157, 745-757.

Gale, A.S., Kennedy, W.J., Voigt, S. \& Walasczech, I. 2005. Stratigraphy of the Upper Cenomanian - Lower Turonian chalk succession at Eastbourne, Sussex, UK: ammonites, inoceramid bivalves and stable carbon isotopes. Cretaceous Research, 26, 460-487.

Gallois, R.W. 1994. Geology of the country around King's Lynn and The Wash (sheet 145 and part of 129). Sheet Description of the British Geological Survey.

Hancock, J.M. 1989. Sea-level changes in the British region during the Cretaceous. Proceedings of the Geologists' Association, 100, 565-594.

Hart, M.B., Simmons, M.D. \& Williams, C.L. 1992. Sequence stratigraphy and sea-level changes in the mid-Cretaceous (Albian to Turonian) of southern England: a preliminary investigation. Proceedings of the Ussher Society, 8, 7-10.

Holland, S.M. 1995. The stratigraphic distribution of fossils. Paleobiology, 21, 92-102.

Jacob, U., Terpstra, S. \& Brey, T. 2003. High-Antarctic regular sea urchins - the role of depth and feeding in niche separation. Polar Biology, 26, 99-104.

Jarvis, I. \& Woodroof, P.B. 1984. Stratigraphy of the Cenomanian and basal Turonian (Upper Cretaceous) between Branscombe and Seaton, SE Devon, England. Proceedings of the Geologists' Association, 95, 193-215.

Lawrence, J. 1987. A functional biology of echinoderms. Croom Helm, London.

Nebelsick, J. 1995. Uses and limitations of actuopalaeontological investigations on echinoids. Géobios, 18, 329-336.

Nebelsick, J. 1996. Biodiversity of shallow-water Red Sea echinoids: implications for the fossil record. Journal of the Marine Biological Association, UK, 76, 185-194.

Neraudeau, D. \& Moreau, P. 1989. Paléoécologie et paléobiogéographie des faunes d'échinides du Cénomanien nordAquitain (Charente-Maritime, France). Géobios, 22, 293-324.

Neraudeau, D. \& Villier, L. 1996. Enregistrement des fluctuations environmentales par les echinides irréguliers de la Craie Campanienne de Charente-Maritime (SO France). Annales de la Société Géologique du Nord, 5, 175-179. 
Neraudeau, D., Thierry, J. \& Moreau, P. 1997. Variation in echinoid biodiversity during the Cenomanian-early Turonian transgressive episode in Charentes (France). Bulletin de la Société géologique de France, 168, 51-61.

Patzkowsky, M.E. \& Holland, S.M. 1993. Biotic response to a middle Ordovician paleoceanographic event in eastern North America. Geology, 21, 619-622.

Patzkowsky, M.E. \& Holland, S.M. 1996. Extinction, invasion, and sequence stratigraphy: patterns of faunal change in the Middle and Upper Ordovician of the eastern United States. In (Witzke, B.J., Ludvigson, G.A. \& Day, J.; eds) Paleozoic sequence stratigraphy: views from the North American craton. Geological Society of America, Special Paper, 306, 131-142.

Robaszynski, F., Gale, A.S., Juignet, P., Amédro, F. \& Hardenbol, J. 1998. Sequence stratigraphy in the Upper Cretaceous series of the Anglo-Paris basin: exemplified by the Cenomanian stage. In (De Graciansky, P-C., Hardenbol, J., Jacquin, T. \& Vail, P.R.; eds) Mesozoic and Cenozoic sequence stratigraphy of European basins. SEPM Special Publication, 60, 363-386.
Smith, A.B., Paul, C.R.C., Gale, A.S. \& Donovan, S.K. 1988 Cenomanian and Lower Turonian echinoderms from Wilmington, south-east Devon, England. Bulletin of the British Museum (Natural History), Geology Series, 42, $1-245$.

Smith, A.B., Gale, A.S. \& Monks, N.E.A. 2001. Sea-level change and rock record bias in the Cretaceous: a problem for extinction and biodiversity studies. Paleobiology, 27, 241-253.

Smith, W.E. 1957. The Cenomanian Limestone of the Beer district, south Devon. Proceedings of the Geologists Association, 68, 115-135.

Smith, W.E. 1961. The Cenomanian deposits of south-east Devonshire. The Cenomanian Limestone, and contiguous deposits, west of Beer. Proceedings of the Geologists' Association, 72, 91-134.

Wright, C.W., Kennedy, W.J. \& Hancock, J.M. 1984. The Ammonoidea of the Lower Chalk. Part 1. Introduction. Monograph of the Palaeontographical Society, 1-37.

Manuscript received 19 February 2005; revised typescript accepted 11 June 2005 